\title{
Indian System of Soil Classification: A way Forward
}

\author{
BB Mishra* \\ Department of Soil Science and Agricultural Chemistry, Bihar Agricultural University, India
}

Submission: November 26, 2016; Published: December 15, 2016

*Corresponding author: BB Mishra, Department of Soil Science and Agricultural Chemistry, Bihar Agricultural University, Sabour 813210, Bhagalpur, Bihar, India, Email: bbmsoil@rediffmail.com

\begin{abstract}
Classification of soil is a powerful tool to utilize our national soil resource purposefully and scientifically. The efforts being made since long past did suffer from common acceptance. In order to present a simplified version of soil classification of Indian soils, efforts are made after thorough discussions and interactions to present this scheme for Indian soils. The approach is not only simple and straight forward, but acceptable to the common farmers and policy makers also as it aims at linking soil resource to land use planning and avoids many taxonomic terms that might be suitable for academic purposes. The system is flexible with a very simple structural framework. It has a strong academic base and it will help to establish a strong background of land use planning in order to ensure productivity, safety, profitability and sustainability in Indian agriculture in days to come.
\end{abstract}

Keywords: Indian system of soil classification; Land use planning

\section{Introduction}

Dr. S. P. Raychaudhuri was the pioneer to integrate pedology with edaphology in India. His contribution with Dr. H. Jenny on the effect of climate and cultivation on nitrogen and organic matter reserves in Indian soils is intended towards sustainability in agriculture Jenny and Raychaudhuri [1]. Soil as a natural resource is the nation's strength that satisfies the human needs at a given time and space. From time immemorial, water is present on the earth, which appears as a curse in the form of flood, but as a resource when used for drinking or irrigation or fishery or even a source of energy in hydro-power generation. Similarly, soil is the most powerful natural resource that contributes to survival and nourishment of all living beings on the earth. However, it is very dynamic in its stage and development due to interactions with surrounding environment (soil site), upwelling and receding water, incoming radiation, diurnal changes in weather components and biodiversity at both macro and micro levels. Soil cannot be a waste and it does not need any rest, though its existence is at risk, if it is degraded or even eroded. The mode of weathering of type specific rocks and minerals leading to a given soil formation depends not only on parent material, relief, biosphere, climate and time, but also on solar radiation as well as management inputs applied Mishra [2].

Soil formation beginning at point zero on regolith or parent material suffers from complex situations including sedentary, fluvial, alluvial, colluvial and manually disturbed soils, which need to be conceptualized further to develop more comprehensive database for quantification and indexing. The soil genesis as a function of both soil forming factors and processes needs to be simplified to some reliable and accepted indexes of common understanding. Factor-process-feature as opined by Dockuchaev, Jenny and Gerasimov may be basic to understand a soil, but current processes and factors are vital in soil classification. As such, classification may preferably rest on present day pedosphere covering diversity in critical zone concept mode of soils. Morpho-genetic approach alone may not work well in soils, because they are heavily manipulated. Some profile features like gleying, mollic and umbric epipedons under ploughed conditions do not make any clear sense. Moreover, soil varies over the landscape, which offers clues as to "what" can best be done and "where" with lowest risks and greatest opportunities. However, soil degradation, on the other hand, is merely an undesirable pedogenic happening that causes certain deviation in soil characteristics from optimal one, that is specific to a given soil group, which can be assessed even by following a simple method based on parametric evaluation as being computed in line with FAO procedures Requier et al. [3]. Thus, classification of a given soil needs revision and validation in time and space in order to maintain productivity, profitability and sustainability. 


\section{Soil Classification Vs Soil Grouping in India}

The Soil classification during ancient period in India was based on whether soil is fertile or sterile i.e. Urvara and Usara. As a matter of fact, India is diversified in geology, relief, climate and vegetation that yield a variety of soil groups. The criteria being applied to classify the Indian soils are based on geology, fertility, relief, chemical composition and physical structure, but with inherent drawback. Even in the district gazetteers and official records during British rule in India, land revenue collection was based on assessment of inherent soil fertility alone without attempting to classify the soil types of India. Prior to independence, limited effort was made to present a Table 1: Broad soil association groups of Bihar [6]. systematic, accurate, complete, comprehensive and need based database for grouping of Indian soils, though Voelcker in 1893, Leather in 1898, Schokalskaya in 1932, Champion in 1936 as well as some Indian experts like Wadia in 1935 and Basu in 1937 including Vishwanath \& Ukil [4] made commendable efforts to classify the Indian soils. Voelcker in 1893 and Leather in 1898 established four major soil groups of India viz. Indo-Gangetic alluvium, black cotton soil or regur, red soil and laterite soil. Subsequently, following the Russian concept of pedology, Schokalskaya presented a soil map of India in 1932 showing 16 soil groups as affected by soil forming inputs including climate, vegetation, salinity, alkalinity, swamps and peats.

\begin{tabular}{|c|c|c|c|c|}
\hline SI. No. & Soil Association & $\begin{array}{l}\text { Extent of } \\
\text { Distribution } \\
\text { (Million Ha) }\end{array}$ & $\begin{array}{l}\text { Agro-Climatic } \\
\text { Zone }\end{array}$ & Special Feature \\
\hline \multirow{2}{*}{1} & \multirow{2}{*}{$\begin{array}{l}\text { Sub Himalayan Hill and } \\
\text { Forest soil }\end{array}$} & \multirow{2}{*}{0.08} & \multirow{2}{*}{ Zone I } & $\begin{array}{l}\text { North west corner of E. Champaran, } \mathrm{pH} \text { neutral to acidic, } \\
\text { high available N, high organic carbon }\end{array}$ \\
\hline & & & & (OC), $50 \%$ soils deficient in $\mathrm{Zn}$ and $15-20 \%$ in $\mathrm{Cu}$. \\
\hline 2 & Recent alluvium & 0.58 & Zone I and II & $\begin{array}{l}\text { In a strip covering Champaran, Sitamarhi, Saharsa and } \\
\text { part of Purnea, pH moderately alkaline, OC and available } \\
\text { NPK medium to high. }\end{array}$ \\
\hline 3 & $\begin{array}{l}\text { Recent alluvium non- } \\
\text { calcareous non-saline soils }\end{array}$ & 1.58 & Zone I and II & $\begin{array}{c}\text { Alluvial plains of Kosi and Mahananda rivers in Purnea, } \\
\text { Saharsa and Madhepura districts including northern part } \\
\text { of Bhagalpur. }\end{array}$ \\
\hline 4 & $\begin{array}{l}\text { Young alluvium calcareous } \\
\text { non-saline soils }\end{array}$ & 0.64 & Zone II & Patches in command area of Kosi region. \\
\hline 5 & $\begin{array}{l}\text { Young alluvium calcareous } \\
\text { soils }\end{array}$ & 1.75 & Zone I & $\begin{array}{l}\text { Mostly along the northern border of Diara land soil } \\
\text { protected from flood, highly productive for most of the } \\
\text { crops. }\end{array}$ \\
\hline 6 & $\begin{array}{l}\text { Young alluvium calcareous } \\
\text { saline and alkali soils }\end{array}$ & 0.24 & Zone I & Widely occurring in Zone I influenced by river Gandak. \\
\hline 7 & Non calcareous alluvial soils & 0.03 & Zone I and II & Mostly in patches in Kosi region as well as part of zone I. \\
\hline 8 & $\begin{array}{l}\text { Recent alluvium calcareous } \\
\text { (Diara land) soils }\end{array}$ & 0.55 & Zone I, II and III & Diara land soil mostly near Ganga river basin. \\
\hline 9 & $\begin{array}{l}\text { Recent alluvium calcareous } \\
\text { yellowish to reddish yellow } \\
\text { non-calcareous non saline } \\
\text { soils }\end{array}$ & 0.28 & Zone II & $\begin{array}{c}\text { Mostly in Kosi region suited to a variety of crops } \\
\text { including jute. }\end{array}$ \\
\hline 10 & $\begin{array}{l}\text { Tal land and related heavy } \\
\text { soils }\end{array}$ & 0.28 & Zone III A and B & $\begin{array}{l}\text { Mostly south of river Ganga showing heavy texture with } \\
\text { wide cracks and quick drying on flood recession. }\end{array}$ \\
\hline 11 & $\begin{array}{l}\text { Old alluvium grey, grayish, } \\
\text { yellow, heavy textured soils }\end{array}$ & 0.58 & Zone III A and B & $\begin{array}{l}\text { Widely distributed in south Bihar, potentially very } \\
\text { productive. }\end{array}$ \\
\hline 12 & $\begin{array}{l}\text { Old alluvium reddish, yellow, } \\
\text { yellow-grey sedentary/ } \\
\text { catenary soils }\end{array}$ & 1.34 & Zone III B & Bhojpur, Rohtas, Patna, Gaya and Aurangabad. \\
\hline 13 & $\begin{array}{l}\text { Old alluvium saline and } \\
\text { alkali soils }\end{array}$ & 0.58 & Zone III B & $\begin{array}{c}\text { Patches in Rohtas district mostly in Chand, Durgavati and } \\
\text { Ramgarh blocks. }\end{array}$ \\
\hline 14 & $\begin{array}{l}\text { Old alluvium yellowish-red, } \\
\text { yellow foot hill soils }\end{array}$ & 0.08 & Zone III B & $\begin{array}{l}\text { Excessively drained shallow to medium deep, moderately } \\
\text { to strongly acidic soils in south Gaya, Aurangabad and } \\
\text { Rohtas. }\end{array}$ \\
\hline 15 & $\begin{array}{l}\text { Hill and forest soils of steep } \\
\text { slopes, highly dissected }\end{array}$ & 0.79 & Zone III B & $\begin{array}{l}\text { Well drained to excessively well drained, moderately to } \\
\text { strongly acidic, light textured with gravels and stones in } \\
\text { South Gaya, Nalanda and Rohtas districts. }\end{array}$ \\
\hline
\end{tabular}


In 1954, the soil survey work was started following the conventional procedures in Bihar (including Jharkhand) to delineate the soil associations (Table 1) based on geology, relief, physical and chemical characteristics of soils for the first time in India by the Soil Survey \& Land Use Planning Scheme at Sabour Jha [5], Mishra et al. [6]. Meanwhile, the National Atlas Organization, Kolkata prepared a soil map of India in 1957 classifying Indian soils into 6 major groups and 11 broad types. However, Wadia and his team in 1935 started a system approach based on geological formation and prepared a soil map of India classifying soils as (a) red, regur (black cotton), laterite and lateritic soils of Peninsular India and (b) delta, desert, terai and sodic soils of Indo-Gangetic Plains. Later, Vishwanath \& Ukil [4] at IARI attempted to prepare a soil map of India based on differing climatic zones. Nevertheless, Raychaudhari et al. [7] for the first time published "Soils of India" based on exhaustive efforts made for integrating the pedogenic relevance of climate, vegetation and relief and established altogether 16 major and 108 minor soil regions under 27 units. Govinda Rajan [8] subsequently revised the soil map of India with 23 major soil groups following the FAO/UNESCO soil classification scheme and refined further with 25 soil classes on a 1:7 million scale map under World Soil Map project. Murthy \& Pandey [9] applied the working principles of the USDA $7^{\text {th }}$ approximation in classifying the Indian soils with available data on soil classes and thus used the US system for the first time at great soil group level, which was transformed into a soil map of India on 1:6.3 million scale. Mishra et al. [10] attempted to propose "Fluvisols" as the $13^{\text {th }}$ Order in USDA Soil Taxonomy for active floodplain soils frequently occurring in different parts of India and elsewhere.

Importantly, the initiatives taken by NBSS \& LUP (ICAR), Nagpur for the last 35 years succeeded in mapping of the soil resource of whole country on 1:7 million scales enabled to recognize 103 sub-orders of soils. Further efforts in 1986 using three-tier approach with image interpretation, field mapping and laboratory data followed by cartography on 1:250,000 large-scale were made for soil mapping Bhattacharya et al. [11]. Bhattacharyya et al. [12], moreover, attempted commendably to compile and classify soils at family level using USDA Taxonomy. In recent development, 24 major soil groups assigned by Govinda Rajan \& Rao [13] were reduced to only 11 major groups (Table 2) by Bhattacharyya et al. [11]. The soil resource mapping programme (SRM) for whole country between 1986 and 1996 enabled to generate huge database on soils, their representative areas and characteristics to facilitate taxonomic groupings (Soil Survey Staff 2006). Bhattacharyya et al. [11] made exhaustive efforts to develop logical relations of differing soil groups in taxonomic terms on different zones of India. All such available information may purposefully be utilized in shaping the soil classification structure in India.

Table 2: Extent and distribution of soils of India as shown in the soil maps on 1:250,000 scale [11].

\begin{tabular}{|c|c|c|c|c|}
\hline \multirow{2}{*}{ Major Soil Groups } & \multicolumn{2}{|c|}{ Extent } & \multirow{2}{*}{ Distribution (States) ${ }^{* *}$} & \multirow{2}{*}{$\begin{array}{l}\text { Corresponding Soil Orders (USDA Soil } \\
\text { Taxonomy) }\end{array}$} \\
\hline & ‘000 ha & Percentage & & \\
\hline Alluvial & 100,006 & 30.4 & $\begin{array}{c}\text { J\&K, HP, Punjab, Haryana, Delhi, UP, Gujarat, } \\
\text { Goa, MP, MS, AP, Karnataka, TN, Kerala, } \\
\text { Pondicherry, Bihar, Odisha, WB, ArP, Assam, } \\
\text { Nagaland, Manipur, Mizoram, Tripura, } \\
\text { Meghalaya, A\&N }\end{array}$ & Inceptisols, Entisols, Alfisols, Aridisols \\
\hline Coastal alluvial & 10,049 & 3.1 & $\begin{array}{l}\text { AP, Karnataka, TN, Kerala, WB, Gujarat, } \\
\text { Odisha, Pondicherry, Lakshadweep, A\&N }\end{array}$ & Aridisols, Insceptisols, Entisols \\
\hline Red & 87,989 & 26.8 & $\begin{array}{l}\text { AP, Karnataka, Kerala, TN, Pondicherry, } \\
\text { Rajasthan, MP, MS, Gujarat, Goa, ArP, Assam, } \\
\text { Manipur, Meghalaya, Nagaland, Mizoram, } \\
\text { Tripura, Delhi, UP, HP, A\&N }\end{array}$ & $\begin{array}{l}\text { Alfisols, Ultisols, Entisols, Inceptisols, } \\
\text { Mollisols, Aridisols }\end{array}$ \\
\hline Laterites & 18,094 & 5.5 & $\begin{array}{c}\text { AP, Karnataka, Kerala, TN, Pondicherry, MS, } \\
\text { Odisha, WB }\end{array}$ & Alfisols, Ultisols, Inceptisols \\
\hline Brown forest & 540 & 0.2 & Karnataka, Maharashtra & Mollisols, Inceptisols \\
\hline Hill & 2,262 & 0.7 & Manipur, Odisha, WB, Tripura, Nagaland & Inceptisols, Entisols \\
\hline Terai & 326 & 0.1 & UP, Sikkim & Mollisols, Entisols \\
\hline Mountain meadow & 60 & - & $\mathrm{J} \& \mathrm{~K}$ & Mollisols \\
\hline Sub-montane & 104 & - & $\mathrm{J} \& \mathrm{~K}$ & Alfisols \\
\hline Black & 54,682 & 16.6 & $\begin{array}{l}\text { MP, MS, Rajasthan, Pondicherry, TN, UP, } \\
\text { Bihar, Odisha, AP, Gujarat }\end{array}$ & $\begin{array}{c}\text { Vertisols, Mollisols, Inceptisols, Entisols, } \\
\text { Aridisols }\end{array}$ \\
\hline Desert & 26,283 & 8 & Rajasthan, Gujarat, Haryana, Punjab & Aridisols, Inceptisols, Entisols \\
\hline Others* & 28,305 & 8.6 & - & - \\
\hline Total & 328,700 & 100 & - & - \\
\hline
\end{tabular}


* Includes glaciers $(0.4 \%)$, sand dunes $(0.01 \%)$, mangrove swamps $(0.04 \%)$, salt waste $(0.01 \%)$, water bodies $(0.1 \%)$, rock land $(0.25 \%)$ and rock outcrops $(7.8 \%)$

**MP, Madhya Pradesh; MS, Maharashtra; UP, Uttar Pradesh; J\&K, Jammu and Kashmir; TN, Tamil Nadu; AP, Andhra Pradesh; ArP, Arunachal Pradesh; WB, West Bengal; HP, Himachal Pradesh; A\&N, Andaman and Nicobar Islands.

\section{Issues and Opportunities}

Soils exist in a very dynamic state purely in open system, wherein exact taxonomic grouping is not very simple, if not impossible, though efforts are being made for unified soil classification as well as universal soil classification. Not only the established soil forming factors are involved, but so many other factors do cause changes in soil unit (pedon). If soil erosion can cause degradation, management in some cases are improving soil's overall features. India is a country of distinctly varied climates, geology, relief and vegetation and thus possessing the distinct varieties of soil groups logically different from one another. Criteria used to classify the Indian soils are primarily based on the geology, relief, morphological features, chemical

Table 3: Dominant clay and clay minerals in Indian soils [14].

\begin{tabular}{|c|c|c|c|}
\hline Soil Group & Location of Samples Examined & Major Clay Minerals Found* & Associated Minerals Found \\
\hline $\begin{array}{l}\text { Desert soils (Lithic Entisols, } \\
\text { Psamments) }\end{array}$ & Jodhpur, Nagpur & $\begin{array}{l}\text { Illite(D), montmorilonite, } \\
\text { attapulgite }\end{array}$ & Kaolinite \\
\hline $\begin{array}{l}\text { Calcareous sierozem soils of } \\
\text { alluvial origin (Calciorthids) }\end{array}$ & $\begin{array}{c}\text { Nilokheri (Haryana), Rothak } \\
\text { (Punjab),Ganganagar (Rajasthan) }\end{array}$ & Illite (D), Chlorite & $\begin{array}{l}\text { Kaolinite, Montmorillonite, Illite- } \\
\text { chlorite, Sepiolite }\end{array}$ \\
\hline Grey Brown soils (Calciorthids) & Ajmer, Pali (Rajasthan) & $\begin{array}{l}\text { Illite or montmorilonite (D), } \\
\text { chlorite or interggrade of } \\
\text { montmorillonite }\end{array}$ & Kaolonite, Illite-chlorite \\
\hline Brown hill soils & $\begin{array}{l}\text { Palampur, Kalimpong } \\
\text { (WB),Kalihar (H.P) }\end{array}$ & $\begin{array}{l}\text { Illite (D), chlorite and } \\
\text { montmorillonite }\end{array}$ & $\begin{array}{l}\text { Illite-chlorite, montmorilonite- } \\
\text { illite }\end{array}$ \\
\hline Submontane soils -podsolic & Srinagar (Kashmir), katrain (HP) & $\begin{array}{c}\text { Illite (D),Chlorite/2:1 or } 2: 2 \\
\text { intergrades }\end{array}$ & Kaolinite-montmorillonite \\
\hline Alluvial soils & Major areas dominatltly & $\begin{array}{c}\text { Dominat mineral is illite or } \\
\text { montmorilonite depending on } \\
\text { nature of alluvium and condition } \\
\text { of weathering. }\end{array}$ & $\begin{array}{c}\text { Kaolinite, mixed layer minerals, } \\
\text { Vermiculites, Quartz }\end{array}$ \\
\hline Terai soils & Foot hills , WB, Uttarkhand & Illite (D), chlorite & Pro-chlorite, Kaolinite \\
\hline $\begin{array}{c}\text { Medium and Deep black soils } \\
\text { (Vertisols) }\end{array}$ & Nagpur, Akola,Maharastra & Montmorillonite & Illite, Kaolinite, Quartz \\
\hline Laterite soils & $\begin{array}{c}\text { Purulia (W.B), Karaikudi (TN), } \\
\text { Ratnagirai (MS) }\end{array}$ & Kaolinite (D), Halloysite & Illite, montmorillonite \\
\hline $\begin{array}{l}\text { Mixed red and black soils } \\
\text { (association of Alfisols and } \\
\text { Vertisols) }\end{array}$ & Mysore, Manasa (MP) & Montmorillonite (D), Illite & Chlorite and Kaolinite \\
\hline
\end{tabular}

${ }^{*} \mathrm{D}$, dominant composition, physical structure and fertility. The soils of Bihar were grouped initially into 15 major soil associations for the first time in India Jha [5], Mishra et al. [6] as presented in Table 1. However, the classification based on these criteria often suffers from drawback and it is seldom possible to have an accurate, complete, interpretative, reliable, comprehensive and generalized framework for classification scheme. Grouping the red, laterite and hilly soils, for example, poses problems due to overlapping of properties. Logically, clays in soil behave almost like the heart in nourishing the plants. Different clay types and clay minerals are found in soils of India Ghosh \& Raychaudhuri [14] as shown in Table 3. There is need to use clay and clay minerals precisely in the soil classification scheme. Mishra et al. [15] attempted to group the dominant clay minerals in the soils of Bihar including Jharkhand (Table 4). However, there is still need to integrate clay science in the framing of soil classification structure. Clay-organic interaction as well as detoxification level of clays may be examined precisely Ghosh and Mishra [16], Mishra and Richa [17], Mishra [2]. 


\section{Agricultural Research \& Technology: Open Access Journal}

Table 4: Major clay associations in soils of Bihar including Jharkhand.

\begin{tabular}{|c|c|}
\hline Major Clay Associations & Major Area \\
\hline $\begin{array}{c}\text { Kaolinite-illite-chlorite (mostly } \\
\text { Chotanagpur plateau) }\end{array}$ & $\begin{array}{c}\text { Ranchi, Palamu, Dumka, } \\
\text { Hazaribagh, Santhal Pargana, } \\
\text { Giridh part of Munger and } \\
\text { Shinghbhum }\end{array}$ \\
\hline $\begin{array}{c}\text { Smectite-illite-kaolinite (mostly } \\
\text { lowland under depressions)s }\end{array}$ & $\begin{array}{c}\text { Patna, Munger, Nawada, } \\
\text { Bhagalpur, Rhotas, Part of } \\
\text { Singhbhum and Rajmahal trap }\end{array}$ \\
\hline Illite-smectite-chlorite & $\begin{array}{c}\text { South Bihar namely Bhojpur } \\
\text { and Rhotas, Tal land soils of } \\
\text { Bhagalpur, Munger and Patna }\end{array}$ \\
\hline
\end{tabular}

Unlike classification for plant, animal and even rock, it is difficult in soil to formulate strict rules about the exclusivity among the numerous characteristics, since the soil is often capable of retaining characteristics that are related to past environment too. Roger [18] argued on soils with a Bt horizon showing together some secondary carbonates, soils composed of kaolinite clay and iron sesquioxides as dominant minerals also indicate the presence of secondary calcium carbonate, soils indicating the hydromorphic features of a hydromorphic soil in an area that does not show any ground water table today, deeply weathered soils showing fresh volcanic glass in the surface horizons, sandy soils with high amount of weather able minerals in an area with strongly leaching environment and remarkably, the soil boundaries within as well as among pedons are rarely sharp. Besides, the transition between well drained and poorly drained soils does usually pass through moderately well and imperfectly drained soils. Such fuzziness makes the definition of clearly defined taxa somehow difficult. Roger [18] further opined that soil scapes are composed of different soil types and the soil classifications built up on a regional, national or even continental basis may be different from classifications covering other regions, nations or continents. Structuring of a classification depends on a number of soils being known and sufficiently characterized, but we are far from harmonizing classification schemes available. Soil surveys across the region do continuously supply the database with information on new soils even and thus allowing an ongoing upgrading of the existing classification systems. This mode of operation will persist for a long period. As such, Roger [18] emphasized that the requirement for only one and fixed soil classification system is not realistic (Figure 1).

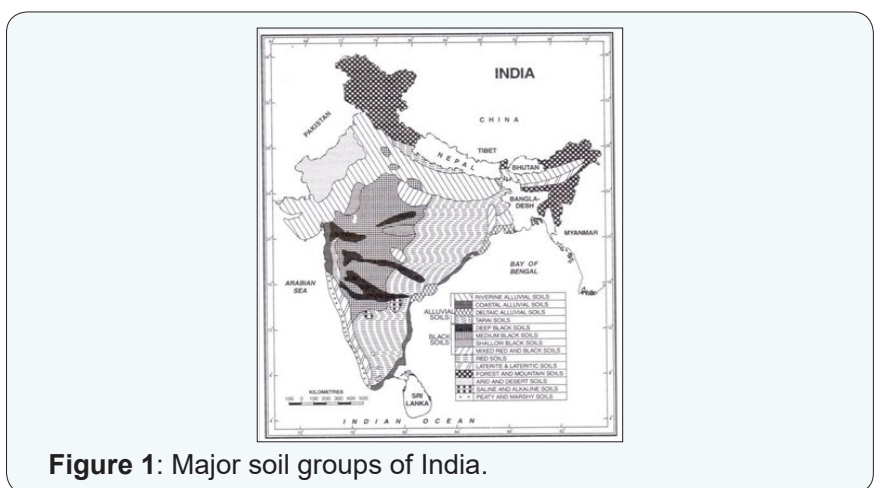

\section{New Approach to Soil Classification}

The existing system of soil classification in India suffers from the following limitations as (i) high number of diagnostic criteria with poor evaluation procedures (ii) soils are often classified by the classifiers who are not the soil taxonomists simply by using unreliable data, since relevant field and analytical data are frequently missing in many places (iii) improving the keys for identification of diagnostic horizons by including all the characteristics that are truly diagnostic and (iv) if we want to sell our expertise, soil classification approach must be demand driven to meet the vital need for productivity, profitability and sustainability in Indian agriculture.

Classification in general involves creation of well defined groups, classes or taxa within multiple entities for common purpose of identification or allocation of an object. Soil classification is often called taxonomy, since the system follows a procedure and criteria that forms the well defined groups, which exists within a set of rules for allocation. Soil is classified using multiple approaches because of complexity and diversity. Variations in soils do occur laterally with space, vertically with depth and temporarily through time. All the parent material, climate, relief, vegetation (including biosphere and biodiversity), time (maturity or stage of development), management (input, process and frequency) and incoming solar radiation (interacting with soil and soil forming other factors) contribute to form the set of factors that dictate the mode of soil forming processes on way to develop a soil as a pedon (Figure 2). The pedon as the unit of soil resource is virtually the building block in a soil classification structure. Soil management and interacting solar radiation are specifically included as the additional soil forming factors Mishra [19], Mishra \& Richa Roy [20], Mishra et al. [21], Mishra [22].

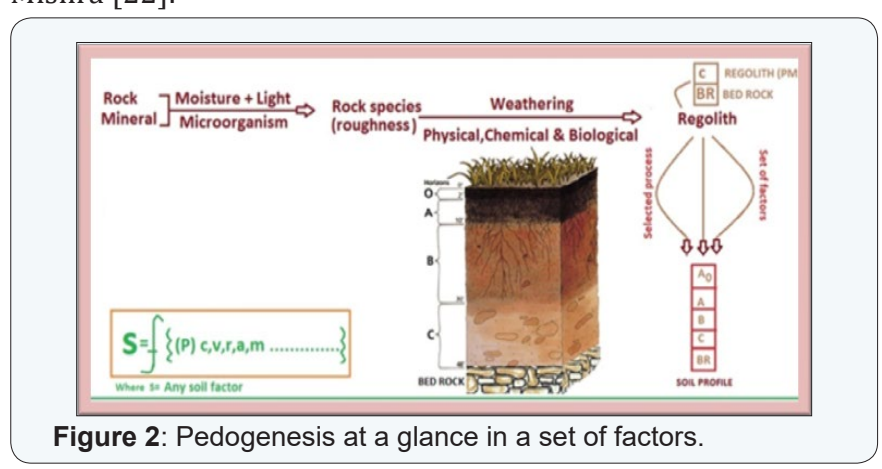

The challenges of capturing the complexity of soil system are not so easy to tackle. Digital soil information transfer towards hypothesise a classification scheme is far from the reality, if land use planning is the goal. The World Reference Base (WRB) for Soil Resources (WRB) gives the definitions and diagnostic criteria of the soil horizons, soil properties and soil materials, which are subsequently used as a key for classifying the reference soil groups and their qualifiers. The WRB is opted for precise definitions of a large number of diagnostic horizons so that the challenges of capturing the complexity of a soil system 
could be harmonized FAO/ISRIC/ISSS [23]. The WRB is thus an easy means of communication to identify, characterize and name major type of soils. However, it does not mean to replace other soil classification systems, but surely to be a tool for better correlation with other systems.

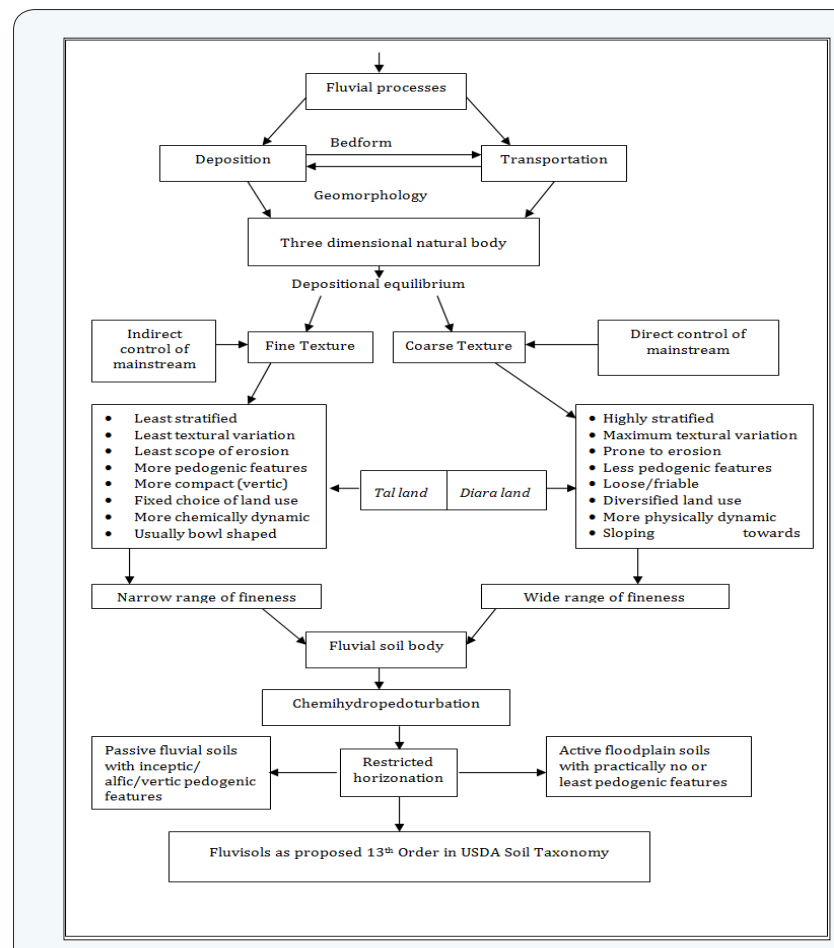

Figure 3: Genesis of proposed Fluvisols in USDA Soil Taxonomy.

Active flood plain soil, for example, develops following a set of scientific laws that need to be documented systematically Mishra [22] so that capturing of associated complexity could be made easy as presented in Figure 3, wherein chemihydropedoturbation is a pedogenic process that works under fluvial system in river or pond Mishra et al. [15]. Similarly, solar radiation initiates interaction with rocks in presence of moisture and facilitates the growth of lichen and similar vegetation leading to soil genesis. Phototrophic bacteria and blue green algae get multiplied many folds on the soil surface in rainy season. These are some examples leading to photopedogenesis Mishra [19], Mishra et al. [21], which can also be considered precisely in structuring the classification.

\section{Towards Indian Soil Classification Vis-à-vis Land Use Planning}

Among soil terminology used, soil classification is perhaps the least popular among common people in India due to missing linkage of its direct applicability to management. The existing classification (USDA Soil Taxonomy) is subject to interpretation to find some suitable management options. Soil classification is discussed under pedology and its linkage to edaphology is merely a customary. Soil is a non-renewable dynamic natural resource, which is subject to production of suitable land use type. The level of productivity is also dynamic and subject to variation, but ready to be enhanced through management. As such, classification scheme in case of soil cannot be static and may be directly linked to management options so that it must be easily acceptable not only to every branch of soil science, but also among common people and farming community for scientific exploitation. How is a soil formed, what set of factors was responsible to assign a well defined process in horizonation of a pedon and whether the soil body is pedogenic or merely disturbed are all related to what is called pedology. Soil as a resource is, however, more related to edaphology, wherein management approach is intended to its relation with plant nutrition and growth. The classification of a soil is thus ultimate expression that must be easily understandable in management terms to the common users and farmers. Lack of mutual relationship between pedology and edaphology during classifying a soil restricts the farmer's acceptance for soil classification and, as a result, this limits its popularity merely within a class-room or in a scientific gathering (Figure 1).

Soils of Indo-Gangetic plains are often deep forming almost levelled plain with imprint of stratification under recent to youthful stage of pedogenesis (Figure 2) particularly in case of tal and diara soils Mishra et al. [15], Mishra [22]. They do differ in their structural orientation from platy to often prismatic via blocky structure. Under soil moisture stress from dryness to wetness in a sub-tropical climate, the length of growing period (LGP) may be considered relevant in classifying the soils. The Vertisols on basaltic hill top (summit) may often be identical to their counterpart in depression (foothill), though the LGP of hill top is much shorter as compared to depression. Stratification as affected by sand layer or even hardpan in a given profile may shrink the LGP. Both LGP and stratification seem to be integral in classification scheme.

Disturbed soils often remain partly attended in the classification schemes. Not only the soils of kitchen gardens or in flower's pots, but most often, agricultural fields are also disturbed or transferred from other plots. The classification scheme must consider the disturbed materials, since they are essentially relevant to agricultural activities. Sand dunes, eroded and truncated materials and fluvial deposits are some other examples similar to disturbed soils, which reflect deviation from pedogenic definition of a soil Mishra [22].

Accordingly, with the bare facts that soil is dynamic and works in an open system as affected by surrounding environment and susceptible to risks, hypothesis is developed that soil classification may not be stable and thus it may be developed in flexible mode. Fortunately, India has a vast database on established groups of soils besides benchmark soils as well as on land use planning projects from different sources. Within such strong background, it was conceived as a vision to develop Indian system of soil classification that must serve the bare need of the farming communities simply by linking the land suitability options so that the system would be demand driven. Accordingly, 
a framework was developed Mishra [24] as a mission in which existing information after due synthesis based on ground truthing would be tested following their validation. The ultimate goal is to integrate classification scheme (Soil group, Soil subgroup and Soil phase) with land suitability so that land use planning could be fixed.

Table 5: Soil groups of India in classification scheme (Highest category).

\begin{tabular}{|c|c|c|}
\hline Soil Group & Central Features & Measurable Characteristics \\
\hline Acidisols & $\begin{array}{l}\text { Acid environment } \\
\text { mostly at high } \\
\text { altitude }\end{array}$ & $\begin{array}{l}\text { High } \mathrm{H}+\text { and } \mathrm{Al} 3+\text { concentration, } \\
\text { low microbial population with } \\
\text { imbalanced nutrient availability }\end{array}$ \\
\hline Calcisols & Calcic in nature & Dominant free $\mathrm{CaCO} 3$ (> 40\%) \\
\hline Desertisols & $\begin{array}{l}\text { Soil with low water } \\
\text { table and dry LGP } \\
\text { (<90 days })\end{array}$ & $\begin{array}{l}\text { Water deficiency causing } \\
\text { chemical and biological } \\
\text { constraints }\end{array}$ \\
\hline Fluvisols & $\begin{array}{l}\text { Under active fluvial } \\
\text { processes }\end{array}$ & $\begin{array}{l}\text { Subject to depositional } \\
\text { equilibrium, irregular settling } \\
\text { of sediments, washing through } \\
\text { flood }\end{array}$ \\
\hline Halosols & $\begin{array}{l}\text { Saline layer with > } \\
25 \mathrm{~cm} \text { depth from } \\
\text { top }\end{array}$ & $\begin{array}{l}\text { Osmotically induced chemical } \\
\text { deterioration, high electrical } \\
\text { conductivity }\end{array}$ \\
\hline Hydrosols & $\begin{array}{l}\text { Marshy and } \\
\text { submerged soil } \\
\text { with redox limits }\end{array}$ & Reduced chemical environment \\
\hline Microbisols & $\begin{array}{l}\text { Sub-temperate } \\
\text { forest soils with } \\
\text { surface litters rich } \\
\text { in microbes }\end{array}$ & $\begin{array}{l}\text { Microbial diversity, } \\
\text { immobilization and more clay- } \\
\text { organic interaction }\end{array}$ \\
\hline Mixisols & $\begin{array}{c}\text { Disturbed, } \\
\text { truncated, eroded, } \\
\text { mixed and } \\
\text { transferred soils (> } \\
25 \text { cm depth from } \\
\text { top) }\end{array}$ & $\begin{array}{l}\text { Subject to attain equilibrium } \\
\text { among physical, chemical } \\
\text { and biological environments } \\
\text { as a result of landslide and } \\
\text { stratification/churning. }\end{array}$ \\
\hline Mollisols & $\begin{array}{l}\text { Identical to forest } \\
\text { and grassland } \\
\text { soils with granular } \\
\text { structure and high } \\
\text { base saturation }\end{array}$ & $\begin{array}{l}\text { Optimal physical, chemical } \\
\text { and biological environment, } \\
\text { occurrence in basaltic landscape } \\
\text { with forest vegetation. }\end{array}$ \\
\hline Natrisols & $\begin{array}{l}\text { Sodicity due to } \\
\text { exchangeable } \\
\text { sodium adsorption }\end{array}$ & $\begin{array}{l}\text { Sodium adsorption causing } \\
\text { physical deterioration and } \\
\text { nutritional imbalance. }\end{array}$ \\
\hline Neutrosols & $\begin{array}{l}\text { Neutral chemical } \\
\text { environment }\end{array}$ & $\begin{array}{c}\text { Conducive to optimal chemical } \\
\text { and biological environments in } \\
\text { mixed environment. }\end{array}$ \\
\hline Plinthosols & $\begin{array}{l}\text { Iron rich yellow } \\
\text { and red soils }\end{array}$ & $\begin{array}{l}\text { Low activity clay and humus poor } \\
\text { soils, red and laterite soils. }\end{array}$ \\
\hline Arenisols & $\begin{array}{l}\text { Sandy layer with } \\
\text { at least }>25 \mathrm{~cm} \\
\text { depth from top }\end{array}$ & $\begin{array}{l}\text { Physically and chemically } \\
\text { instable, river basin and coastal } \\
\text { soils. }\end{array}$ \\
\hline Regosols & $\begin{array}{l}\text { Imprint of parent } \\
\text { materials }\end{array}$ & $\begin{array}{l}\text { Shallow gravelly soils with } \\
\text { stoniness, eroded and slopy } \\
\text { landform. }\end{array}$ \\
\hline
\end{tabular}

\begin{tabular}{|c|c|c|}
\hline Siltosols & $\begin{array}{c}\text { Silt layer with }>25 \\
\text { cm depth from top }\end{array}$ & $\begin{array}{c}\text { Physically and chemically active } \\
\text { with more soil water storage, } \\
\text { river basin and foothill soils. }\end{array}$ \\
\hline Vertisols & $\begin{array}{c}\text { High smectitic } \\
\text { clays and clay } \\
\text { minerals }\end{array}$ & $\begin{array}{c}\text { Swell-shrink properties as in } \\
\text { black cotton and tal land soils }\end{array}$ \\
\hline Uttamisols & $\begin{array}{c}\text { Undefined soils } \\
\text { across the country }\end{array}$ & $\begin{array}{c}\text { Diagnostic characteristics to } \\
\text { be established for distinction } \\
\text { from others with specific } \\
\text { nomenclature (separate Soil } \\
\text { Group) }\end{array}$ \\
\hline
\end{tabular}

Table 6: Soil sub-groups assigned to Soil groups.

\begin{tabular}{|c|c|c|}
\hline Sr. No. & $\begin{array}{c}\text { Soil sub-group } \\
\text { (potentiality of a soil) }\end{array}$ & $\begin{array}{l}\text { Specific traits of the soil } \\
\text { potential }\end{array}$ \\
\hline \multirow{4}{*}{1} & $\begin{array}{l}\text { Mode of profile } \\
\text { arrangement }\end{array}$ & Stratification \\
\hline & & Compactness \\
\hline & & Hardpan \\
\hline & & Regular \\
\hline \multirow{5}{*}{2} & $\begin{array}{l}\text { Effective depth of soil } \\
\text { profile }\end{array}$ & Shallow $(<25 \mathrm{~cm})$ \\
\hline & & Slightly deep $(25-50 \mathrm{Cm})$ \\
\hline & & Moderately deep $(50-100 \mathrm{~cm})$ \\
\hline & & Deep $(100-150 \mathrm{~cm})$ \\
\hline & & Very deep $(>150 \mathrm{~cm})$ \\
\hline \multirow{3}{*}{3} & $\begin{array}{l}\text { Length of growing } \\
\text { period (LGP) }\end{array}$ & Moist ( $>180$ days) \\
\hline & & Dry and moist ( $90-180$ days) \\
\hline & & Dry (<90 days) \\
\hline \multirow{5}{*}{4} & $\begin{array}{l}\text { Dominant clay } \\
\text { minerals }\end{array}$ & Kaolinite-Halloysite \\
\hline & & Illite-Vermiculite \\
\hline & & Smectite/Montmorillonite \\
\hline & & Chlorite \\
\hline & & Mixed \\
\hline \multirow{4}{*}{5} & $\begin{array}{l}\text { Textural arrangement } \\
\text { below } 25 \mathrm{~cm} \text { depth }\end{array}$ & Sandy loam \\
\hline & & Loam \\
\hline & & Silt loam \\
\hline & & Clay loam \\
\hline \multirow{5}{*}{6} & Slope gradient & Leveled $(<2 \%)$ \\
\hline & & Slight (2-3\%) \\
\hline & & Gentle (3-5\%) \\
\hline & & Moderately (5-15\%) \\
\hline & & Steep $(>15 \%)$ \\
\hline
\end{tabular}

\section{Soil Classification Structure}

The highest category named "Soil Group" relates to the inherent soil qualities and altogether 17 Soil groups are assigned in the first hand approach (Table 5). Followed by this is the Soil sub-group which consists of six components relevant to the soil potentiality (Table 6). The soil sub-group will follow 
the Soil phase (consisting of five categories of constraints) that refers to the limitations associated with the actual productivity of a soil (Table 7). Both Soil sub-group and Soil phase during classification help in identifying the limitations associated with the soils so that improvement could be made possible by suitable management options (Land suitability).

Table 7: Assignment of phases as the constraints against soil productivity.

\begin{tabular}{|c|c|c|}
\hline Soil Phase & $\begin{array}{c}\text { Characteristics Associated with } \\
\text { Soil Productivity }\end{array}$ & Level \\
\hline $\begin{array}{c}\text { Soil fertility level } \\
\text { Low organic matter, nutrient } \\
\text { availability and their interaction } \\
\text { state. }\end{array}$ & I \\
\hline $\begin{array}{c}\text { Soil physical } \\
\text { constraints }\end{array}$ & $\begin{array}{c}\text { Drainage, water storage capacity, } \\
\text { temperature, gravels \& stones. }\end{array}$ & II \\
\hline $\begin{array}{c}\text { Soil chemical/ } \\
\text { mineralogical } \\
\text { constraints }\end{array}$ & $\begin{array}{c}\text { Low CEC, high reduceable Fe } \mathrm{O}_{3}, \text { high } \\
\text { gypsum, oxidic materials, quartz etc. }\end{array}$ & III \\
\hline $\begin{array}{c}\text { Soil sickness/ } \\
\text { predators }\end{array}$ & $\begin{array}{c}\text { Microbial imbalance, termites, } \\
\text { protozoa, nematodes, soil borne } \\
\text { diseases. }\end{array}$ & IV \\
\hline
\end{tabular}

As already reported Mishra [25], the classification structure for a given soil may be written in sequence as Soil Group-Soil Subgroup- Soil Phase following the identification of associated limitations and subsequent correction through improvement measures in order to assign the most preferred land use choice in rotation (land suitability). In classification process, each soil group, for example, Fluvisol will include all six subgroups and associated phases in order to resolve the limitations for management option so that the land use planning may be specifically defined in the classification scheme itself (Table 8).

Table 8: Example to classify an Indian soil following scientific management.

\begin{tabular}{|c|c|c|c|}
\hline $\begin{array}{c}\text { Soil } \\
\text { Group }\end{array}$ & Sub-Group & $\begin{array}{c}\text { Soil } \\
\text { Phase }\end{array}$ & $\begin{array}{c}\text { Most Preferred Land } \\
\text { use Choice (Rotation) }\end{array}$ \\
\hline Fluvisol & $\begin{array}{c}\text { Stratified, very deep, } \\
\text { dry \& moist, mixed, } \\
\text { loam, gentle }\end{array}$ & I, II, V & $\begin{array}{c}\text { Kalai (Phaseolus mungo)- } \\
\text { Maize (Zea mays)-Cheena } \\
\text { (Panicum millaccum) }\end{array}$ \\
\hline
\end{tabular}

\section{Future Plan}

Since 1893, efforts have been made to classify the soils of India with considerable success. The proposed 17 Soil groups are assigned to major soils of India at the highest level followed by Sub-groups (consisting of six potentially viable soil features for each Soil group) and Soil phase (consisting of five distinguishing constraints related to soil productivity). A classified soil may enable to identify the associated limitations for correction through the process of improvement measures in order to assign the most remunerative land use choice in rotation. The classification scheme is not only simple and acceptable, but an effective tool to integrate the conventional soil survey, land evaluation and land use planning with land suitability by merging the pedogenic aspects with edaphology. This further necessitates an opportunity to re-define a soil in management terms.
The intention as conceived from WRB was to work towards development of a framework through which ongoing national soil classification programme could be harmonized. The only objective is to reach an agreement on proposed taxonomic groupings of Indian soils through exchange of additional information as well as experience so that common scientific language could be developed to strengthen "A Model for Soil Classification System in India".

The soil is highly dynamic in time and space in an open system and so its classification would also be changing in an interval that will vary according to surrounding and inherent conditions. As such, soil classification as an indicator of the land use planning would work directly for farming communities and justify as a tool to control food security, food safety and livelihood in a big way. The road map of the country based on soil classification would now help the policy makers to come up with reliable outcome through land use planning.

\section{Epilogue}

Soil is the true foundation base to connect our life with food, air, water, climate, biodiversity and even energy for survival and nourishment. It is not only a huge reservoir of biodiversity, but also works for protective medical treatments. It is a source of construction and raw material as well as used in industry and nanotechnology even. Prime agriculture land without healthy soil is far off the truth and evidence. So, there is need to follow a work culture in soil science. Shrinkage of farm land either due to erosion or degradation or even non-farming activities like construction of houses or roads is the most terrifying consequence causing climate change and carbon emission. Evergreen or conservation agriculture is the most powerful mitigation option to combat with challenges of climate change. There is thus need to develop a strong global support in order to pay true respect to soil. The road map of agriculture without proper soil evaluation and land use suitability classification is virtually a missing gap, because ignorance of truth and reality results into disastrous consequences. The classification scheme for Indian soils will integrate soil qualities with soil health, associated limitations and land use suitability. The World Soil Day campaign aims to connect people with soil and raise awareness on its vital importance in our lives for gross happiness. Let's begin to work on Indian Soil Classification Scheme and link directly to land use planning options in order to assure gross rural happiness as a historic mark of the International year of soil science 2015 in India.

\section{Future Line of Action}

The Classification scheme forwarded is simple, reliable, flexible and acceptable at farm level without imposing any complexity of nomenclature and diagnostic features. The researchers and students should verify its reliability in order to promote the effective utilization of land use planning in days to come. 


\section{Acknowledgements}

Thanks to WCSS for accepting this paper for presentation during both $19^{\text {th }}$ and $20^{\text {th }}$ WCSS at Brisbane in Australia in 2010 and Jellu in S. Korea in 2014, respectively. Dr. Jagdish Prasad, Dr. Rajeev Srivastava and Dr. A. Chaturvedi, National Bureau of Soil Survey \& Land Use Planning, Nagpur is thankfully acknowledged for technical comment. Thanks to Nagpur Chapter of the Indian Society of Soil Science at NBSS \& LUP for inviting me to deliver the $26^{\text {th }}$ Dr. S.P.Raychaudhuri Memorial Lecture on $19^{\text {th }}$ October, 2015.

\section{References}

1. Jenny H, Raychaudhuri, Satya Prasad (1960) Effect of climate and cultivation on nitrogen and organic matter reserves in Indian soils. ICAR, New Delhi, India.

2. Bhattacharyya T, Sarkar D, Sehgal J, Velaytham M, Gajbhiye KS,et al. (2009) Soil Taxonomic Database of India and the States $11: 250,000$ scale). NBSS\&LUP 143: 266.

3. Riquier J, Bramao DL, Cornet J (1970) A New System of Soil Appraisal in Terms of Actual and Potential Productivity (First Approximation). FAO, Soil Resources, Development and Conservation Service, Land and Water Development Division, Approaches to Land Classification, Soil Bull, 22 FAO, Rome, Italy, pp. 120.

4. Vishwanath B, Ukil AC (1943) Soil Map of India. Indian Council of Agricultural Research, New Delhi, India.

5. Jha PP (1972) Soils of Bihar. In Soils of India, Fertiliser Association of India Pub, New Delhi, India.

6. Mishra BB, Mall J, Choudhary J, Singh RA (2001) Nutrient mining in different agro climatic zones of Bihar. Fertiliser News 46(11): 21-43.

7. Raychaudhari SP, Aggrawal RR, Datta Biswas NR, Gupta SP, Thomas PR (1963) Soils of India. Indian Council of Agricultural Research, New Delhi, India.

8. Govinda Rajan SV (1971) Soil Map of India. In. Kanwar Js and Raychaudhuri (Eds), Review of Soil Research in India 1: 7.

9. Murthy RS, Pandey S (1983) Soil Map of India (1:6.3 m). NBSS\&LUP, ICAR, Nagpur, India.

10. Mishra BB, Choudhary CD, Singh NK, Mall J (1994) Fluvisol as a proposed Order in soil Taxonomy for active flood plain soils. Trans $\mathrm{XV}^{\text {th }}$. World Congress of Soil Science, Acapulco, Mexico, USA, 6B: 55-56.

11. Bhattacharyya T, Pal DK, Mandal C, Chandran C, Ray SK, et al. (2013) Soils of India: Historical perspective, classification and recent advances. Current Science 104(10): 1308-1323.
12. Bhattacharyya T, Sarkar D, Sehgal J, Velaytham M, Gajbhiye KS,et al. (2009) Soil Taxonomic Database of India and the States (1:250,000 scale). NBSS\&LUP 143: 266.

13. Govind Rajan SV, Rao Gopal HG (1978) Studies on soils of India. Vikas Pub. House Pvt Ltd, New Delhi, India.

14. Ghosh SK, Raychaudhari SP (1974) Distribution of clay minerals in Indian soils. In. Mukherjee SK and MukherjeeMineralogy of Soil Clays \& Clay Minerals, Indian Society of Soil Science, pp. 143-163.

15. Mishra BB, Mall J, Singh RA, Choudhary J (1996) Clay mineral associations occurring in major soil groups of Bihar. Clay Research 15(2): $15-24$.

16. Ghosh SK, Mishra BB (1989) Clay-organic interactions. Clay Research 8(1-2): 84-90.

17. Mishra BB, Richa Roy (2015) Soil science vs medical science: Breakthrough in science for medicine. Business of Agriculture, p. 3841.

18. Roger, Langohr (2002) Facing basic problems in the discipline of soil classification: Conclusions based on 35 years practice and teaching. European Soil Bureau Research 7: 15-25.

19. Mishra BB (1996) Theory of photopedogenesis. Journal of Indian Society of Soil Science 44(3): 541-543.

20. Mishra BB, Richa Roy (2015) Soil science vs medical science: Breakthrough in science for medicine. Business of Agriculture, p. 3841.

21. Mishra BB, Heluf G, Sheleme B (2006) Photopedogenesis: Concept and Application. Journal Food Agriculture \& Environment (Finland) 4: 1214.

22. Mishra BB (2015b) Soil Based Integrated Management Inputs for Flood and Flood Plain Soils of Bihar, India. EC Agriculture 1.2 (2015): 109123.

23. FAO/ISRIC/ISSS (1998) World Reference Base for Soil Resources. World Soil Resources Report, 84, FAO, Rome, Italy.

24. Mishra BB (2013) Proposed Framework for Indian System of Soil Classification Scheme. In. National Symposium on "Application of Clay Science in Agriculture, Environment \& Industry", New Delhi, India, pp. 04-08.

25. Mishra BB (2015c) Soil Classification: Issues and Opportunities for Indian System, the $26^{\text {th }}$ Dr. SP Raychaudhuri Memorial Lecture, $19^{\text {th }}$ October, 2015, NBSS \& LUP, Nagpur, Journal of the Indian Society of Soil Science 63 (Supple): S41-S52.

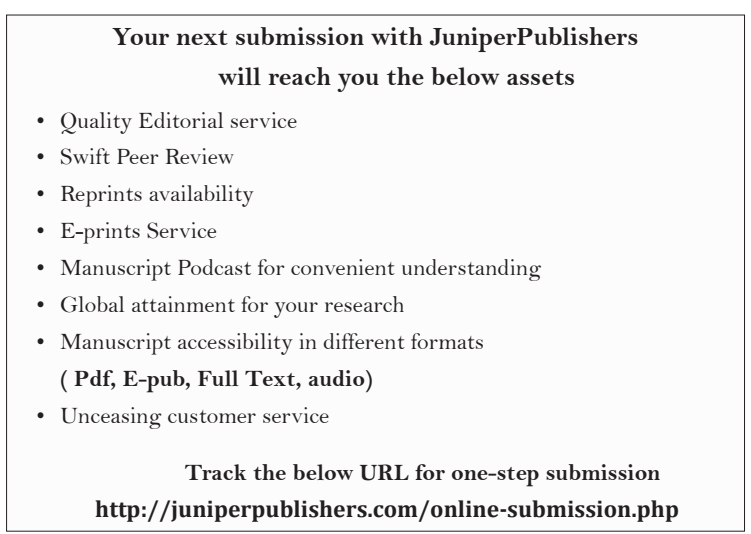

